Abstracta Iranica Abstracta Iranica

Revue bibliographique pour le domaine irano-aryen

Volume 28 | 2007

Comptes rendus des publications de 2005

\title{
«The Role of Water Exports in Iranian Foreign Policy towards the GCC ». Iranian Studies, 38/2, 2005, pp. 311-328.
}

\section{Bernard Hourcade}

\section{(2) OpenEdition}

1 Journals

\section{Édition électronique}

URL : http://journals.openedition.org/abstractairanica/19601

DOI : 10.4000/abstractairanica.19601

ISSN : 1961-960X

Éditeur :

CNRS (UMR 7528 Mondes iraniens et indiens), Éditions de l'IFRI

\section{Édition imprimée}

Date de publication : 15 mai 2007

ISSN : 0240-8910

Référence électronique

Bernard Hourcade, " «The Role of Water Exports in Iranian Foreign Policy towards the GCC ». Iranian Studies, 38/2, 2005, pp. 311-328. », Abstracta Iranica [En ligne], Volume 28 | 2007, document 451, mis en ligne le 18 septembre 2007, consulté le 25 septembre 2020. URL : http://journals.openedition.org/ abstractairanica/19601 ; DOI : https://doi.org/10.4000/abstractairanica.19601

Ce document a été généré automatiquement le 25 septembre 2020.

Tous droits réservés 


\section{«The Role of Water Exports in} Iranian Foreign Policy towards the GCC ». Iranian Studies, 38/2, 2005, pp.

\section{1-328.}

\section{Bernard Hourcade}

1 Après avoir considéré les pays arabes de la rive sud du golfe Persique (GCC) comme des alliés des États-Unis, notamment pendant la guerre Irak-Iran, la République islamique cherche depuis 1990 à créer des liens durables avec ces pays. Dans ce contexte, la fourniture d'eau venant du Kārūn et de la KarHुe à Qatar et Koweït constitue un projet stratégique, mais dont les négociations n'ont pas abouti, surtout pour des raisons politiques et à cause de l'influence américaine. Cet article fait longuement l'histoire des relations Iran-GCC, mais ne donne que peu d'informations techniques sur ces projets de grande importance écologique et politique.

\section{INDEX}

Thèmes : 13.1. Iran

\section{AUTEURS}

BERNARD HOURCADE

CNRS / Mondes iranien et indien - Paris 